\title{
HEXAGONAL MANAGEMENT KELAS DALAM PEMBELAJARAN DI SEKOLAH DASAR
}

\author{
Daniel Dike ${ }^{*}$, Lusila Parida ${ }^{1}$ \\ 1STKIP Persada Khatulistiwa Sintang \\ 1J1. Pertamina Km 4, Sengkuang, Sintang, Kapuas Kanan Hulu, Kalimantan Barat, Indonesia \\ *Corresponding Author. Email: dikedanieltukan@gmail.com
}

\begin{abstract}
Abstrak
Penelitian ini bertujuan memetakan suatu gambaran pemanfaatan kelas sebagai episentrum pembelajaran secara maksimal melalui penguatan manajemen kelas. Disain penelitian ini menggunakan case study research. Penelitian ini mengkaji fenomena dan fakta pembelajaran di kelas melalui observasi partisipan, wawancara mendalam dan studi dokumentasi serta angket respon siswa terhadap aktivitas belajar mengajar yang dilakukan guru dan siswa di SD Panca Setya 2 Sintang, Kalimantan Barat. Data divalidasi dengan triangulasi sumber dan teknik kemudian dianalisis dan ditarik kesimpulan secara induktif. Hasil penelitian menunjukan bahwa kelas dan pembelajaran belum sepenuhnya menjadi pusat atau episentrum pembelajaran yang kuat meskipun pada aspek perencanaan, pengorganisasian, implementasi dan evaluasi belajar yang dilakukan guru sudah cukup baik. Respon siswa menunjukkan bahwa pada keempat aspek tersebut belum berjalan secara ideal sesuai harapan siswa kerena kelas belum sepenuhnya dikelola secara maksimal. Solusi mengatasi persoalan ini bisa dilakukan dengan menerapkan manajemen hexagonal yang memiliki enam kekuatan sentral yakni karakteristik siswa, sikap guru, infrastruktur kelas, infrastruktur teknologi, dukungan sekolah, dukungan yayasan atau dinas pendidikan. Bila pembelajaran di kelas mengintegrasikan peran sentral keenam aspek manajemen hexagonal maka kelas akan sungguh-sungguh menjadi pusat gravitasi pembelajaran efektif, produktif dan bermakna.

Kata kunci: managemen kelas, episentrum pembelajaran, management hexagonal
\end{abstract}

\section{CLASS HEXAGONAL MANAGEMENT IN ELEMENTARY SCHOOL LEARNING}

\begin{abstract}
This study aims to map a picture of class use as the epicenter of learning and strengthening classroom management. This research design uses a case study research. This study explores the phenomena and facts of learning in the classroom at Panca Setya 2 Elementary School, in Sintang of West Kalimantan. The data collecting by participant observation, in-depth interviews and documentation studies as well as student response questionnaires to teaching and learning activities carried out by teachers and students. Data is validated by source triangulation and techniques then analyzed and drawn inductively. The results of the research show that class and learning have not yet fully become the center or strong epicenter of learning even though the aspects of planning, organizing, implementing and evaluating the learning done by the teacher are good enough. Students' responses show that the four aspects have not run ideally according to student expectations because the class has not been fully managed maximally. The solution to overcome this problem can be done by implementing hexagonal learning management because it is believed to be able to turn on six key aspects of learning so that the class truly becomes the center of effective and optimal learning gravity.
\end{abstract}

Keywords: class management, learning epicenter, hexagonal management

Permalink/DOI: http://dx.doi.org/10.21831/amp.v7i1.23268 


\section{Pendahuluan}

Proses belajar yang berhasil tentu membutuhkan ruang kelas yang dikelola sebagai pusat atau episentrum belajar (Dewey, 1900, p. 41) yang memungkinkan setiap anak menjadi pusat gravitasi dari kegiatan belajar itu sendiri. Namun dalam kenyataan pembelajaran di sekolah dasar daerah pedalaman memiliki perspektif kelas dengan yang masih berpola konvensional. Ruang kelas dengan tata meja dan kursi yang paten dan cukup sempit membuat guru selalu melihat dan memperlakukan kelas dengan skenario belajar satu arah dan homogen dengan beberapa variasi penataan kelas berpola U,O dan T. Problem klasikal kelas adalah satu tindakan belajar guru berlaku bagi semua anak sementara kebutuhan belajar dan cara belajar setiap anak dapat sangat beragam. Kelas-kelas sekolah dasar belum begitu kreatif karena belum terlihat masifnya inovasi guru baik terhadap materi ajar, media, metode serta infrasturktur kelas dan teknologi yang masih sangat minim untuk melayani kebutuhan belajar siswa yang beragam.

Fenomena umum di ruang-ruang kelas sekolah dasar di wilayah pedalaman tergambar dominan sebagai aktivitas transfers pengetahuan dan bukan sebagai konstruksi pengetahuan dan keterampilan sosial. Guru dibebani dan membebani dirinya untuk memenuhi target materi yang padat sesuai kurikulum dengan tugas pendampingan lainnya. Konsep bahwa sekolah merupakan suatu lingkungan jejaring baru bagi anak dalam proses sosialnya untuk mengembangkan pengetahuan dan kapasitas-kapasitas sosialnya belum terbangun secara baik. Proses belajar yang bertujuan membangun dan membaharui pengalaman siswa melalui interaksi informasi, komunikasi dengan lingkungan sosial melalui elemen-elemen belajar yang diciptakan secara sengaja maupun tidak sengaja dalam proses belajar di kelas maupun di luar kelas belum berjalan maksimal. Upaya mengembangkan pengetahuan, nilai-nilai, sikap serta keterampilan alamiah siswa yakni hasrat membangun jaringan dan komunikasi dengan orang lain, membangun cita-cita, memperbesar harap- an untuk mencari tahu, menanyakan, menyelidiki, bereksperimen mengenai berbagai hal justru banyak dimatikan oleh pola belajar satu arah dan konstruksi infrastruktur kelas yang kaku dan minim teknologi. Tujuan belajar sebagai investasi masyarakat dalam mengembangkan kapasitas sosial siswa membangun masyarakat masa depan yang lebih baik belum berjalan secara maksimal. Artinya proses belajar yang berkembang sebagian besar masih pada level skenario literer dan spesifik pada kontenkonten khusus mengejar target penguasaan kemampuan sains, matematika, dan linguistik (Claxton, 2014, pp. 4-7) .

Manajemen kelas yang perlu dikembangkan guru dalam proses belajar mengajar di sekolah dasar belum memungkinkan setiap siswa untuk mengekspresikan diri mereka secara lebih artistik (Glassman, 2002 , p. 4). Sebelum proses belajar itu berlangsung sebenarnya guru sendiri telah memiliki rencana dan tujuan eksplisit maupun implisit. Artinya, setiap hari melalui tatap muka guru harus memiliki perencanaan terukur dan dikelola secara interaktif baik menyangkut materi ajar, media, metode, infrastruktur kelas maupun infrastruktur teknologi. Kapasitas guru maupun siswa di sekolah dasar wilayah pedalaman dengan infrastruktur kelas, teknologi, dukungan lembaga dan pemerintah yang belum maksimal namum dari visi manajemen kelas perlu dipacu dengan model atau visi manajemen belajar sukses (success learning model). Penting bagi guru untuk memiliki kemampuan managerial dan pengorganisasian kelas serta kepekaan kuat dalam memahami perilaku siswa karena kadang-kadang siswa merasa gelisah dalam aktivitas belajarnya karena ia mengalami ketidaknyamanan fisik dari pada situasi atau perasaan kebosanan oleh aktivitas belajar yang mereka lakukan bersama guru di kelas (Hastings, 2006, p. 143). Penciptaan awal kondisi dan konfigurasi ruang kelas menjadi titik awal yang menentukan keberhasilan proses dan aktivitas belajar siswa di kelas.

Sistem mutu harus dimiliki oleh sekolah dan dipahami dengan baik oleh guru dalam implementasi proses belajar yang 
berkualitas di ruang kelas. Hal yang wajib dimiliki sekolah adalah mutu layanan belajar bahwa keterampilan menata dan mengelola kelas sangat menentukan keberhasilan belajar dan capaian target kurikulum yang dirancang oleh pihak sekolah secara terukur dan realistik.

Tahapan evaluasi proses belajar harus memperhatikan dan melibatkan semua aspek dan elemen mutu yang dalam perspektif managemen hexagonal. Aspek mutu dalam tahapan evaluasi harus memperhatikan lima aspek dalam sistem mutu yakni kualitas informasi dan pengetahuan yang diajarkan, kualitas layanan dalam proses belajar, sistem dan metode belajar serta kepuasan belajar.

Guru harus menyadari bahwa kelas adalah realitas yang beragam bukan homogen, sebab itu ruang kelas secara fisik dan psikologis harus mampu menyediakan dan memfasilitasi kebutuhan belajar siswa yang beragam secara sosial, emosional dan psikologis dengan daya dukung infrastuktur kelas dan teknologi secara maksimal (Ozkan, 2015, p. 6; Selim, 2007,p. 395). Bahkan, lebih luas lagi dalam konteks belajar di kelas dan di luar kelas membutuhkan daya dukung penuh dari yayasan, pemerintah dan masyarakat karena semua elemen tersebut menjadi faktor penentu tingkat kritis sukses belajar siswa.

Penelitian ini menyoroti bagaimana implementasi manajemen kelas yang diterapkan guru di sekolah dasar dan menawarkan suatu kerangka teoretik pengembangan tata kelola manajemen kelas yang lebih membantu guru untuk menciptakan kelas sebagai episentrum pembelajaran sukses dalam arti menjadi lebih baik dan produktif.

\section{Metode Penelitian}

Penelitian ini menggunakan case study research. Studi kasus ini dipilih karena menjadi sarana penelitian emik yakni menyajikan pengalaman subjek yang diteliti serta keunikan situasionalnya, serta menyajikan uraian menyeluruh sesuai dengan pengalaman sehari-hari (everyday real life) (Stake, 2005, pp. 443-445). Pengalaman riil yang dimaksud adalah terkait situasi belajar dan infrasturktur kelas serta perencanaan, pengorganisasian, implementasi (pelaksanaan) dan evaluasi belajar yang dilakukan guru di kelas.

Penelitian ini dilakukan di Sekolah Dasar Panca Setya 2 Sintang. Pemilihan lokasi penelitian menggunakan teknik purposive. Pertimbangan pemilihan sekolah ini karena karakteristik khusus sebagai sekolah swasta Katolik yang memiliki prestasi dengan kategori akreditas A atau sekolah unggul dengan spesifikasi kelas adalah siswa kelas dua Waktu penelitian ini dilaksanakan selama tiga bulan dari September, Oktober dan November tahun 2018.

Subjek penelitian yang digunakan dalam penelitian ditentukan secara purposive sampling yakni kepala sekolah, guru dan siswa. Subjek data sebanyak 68 orang dengan rincian 3 guru kelas, 1 kepala sekolah dan 64 siswa. Partisipan ini dipilih karena dipercaya memiliki kapasitas informasi relevan terkait implementasi dan manajemen pembelajaran di kelas.

Penelitian studi kasus ini memfokuskan pada manajemen pembelajaran yang berpusat pada apa yang dilakukan guru di kelas terkait perencanaan, pengorganisasian, penerapan (implementasi) dan evaluasi pembelajaran guru dengan melihat apa, mengapa dan bagaimana manajemen pengelolaan kelas itu diterapkan dalam pembelajaran sehari-hari guru di kelas (Ary, Jacobs, Sorensen, \& Razavieh, 2006, p.29). Sedangkan siswa adalah sebagai subjek pembanding untuk menentukan respon balik terhadap implementasi manajemen kelas yang didisain guru melalui angket. Penelitian ini menyoroti desain manajemen kelas dan model otoritas yang guru terapkan dalam proses belajar sehingga bisa terlihat seberapa jauh kelas dan pembelajaran telah menjadi pusat gravitasi atau episentrum belajar yang efektif dan produktif.

Perolehan data dilakukan dengan wawancara mendalam terhadap empat aspek kunci dari manajemen kelas yakni perencanaan, pengorganisasian, penerapan dan evaluasi pembelajaran serta model otoritas guru dan respon yang diberikan oleh siswa 
dari penerapan manajemen kelas. Disain studi kasus ini menggabungkan berbagai data baik data observasi, wawancara, studi dokumen maupun dan angket, yang secara mendalam mengelaborasi praktik manajemen kelas oleh guru sesuai konteks sosial sekolah melalui berbagai sumber data yang valid (Jansen, 2010, p. 6). Pusat amatan adalah kegiatan dan aktivitas guru dan siswa dalam proses pembelajaran di kelas 2A, 2B, dan 2C SD Panca Setya 2 Sintang. Kelas dua dipilih dengan pertimbangan untuk melihat respon tingkat kepuasan belajar siswa setelah satu tahun mengikuti dinamika, adaptasi belajar di sekolah dasar. Proses dan dinamika belajar yang guru dan siswa lakukan dicatat dan kemudian disusun sebagai hasil temuan kemudian dikomparasikan dengan data hasil wawancara, studi dokumen serta angket melalui metode triangulasi sehingga diperoleh hasil yang valid.

Draft wawancara dan observasi yang diketik melalui komputer kemudian dikaji secara teliti untuk meminimalisir informasi yang tidak relevan. Partispan kemudian diminta konfirmasinya kembali terhadap simpulan transkrip wawancara dan observasi yang sudah dirangkum. Semua data yang diperoleh dari hasil wawancara dan amatan memiliki kontribusi secara langsung atau tidak langsung dengan berbagai sumber dan perspektif melalui proses triangulasi dengan tujuan meningkatkan akurasi akurasi dan keandalan data (Ary et al., 2006, pp. 498-499). Yang menjadi unit analisis adalah guru dan siswa yang menjadi bagian penting dan saling terkait satu sama lain dari implementasi manajemen kelas dan model otoritas yang diterapkan dalam pembelajaran. Seluruh sajian dan analisis data tersebut bermuawa pada satu kesimpulan secara induktif (Baxter \& Jack, 2008, pp. 554-555).

\section{Hasil Penelitian dan Pembahasan}

Hasil riset ini mendeskripsikan aspekaspek penting sesuai rumusan pertanyaan penelitian yakni; bagaimana implementasi manajemen pembelajaran terkait empat unsur pokok pembelajaran guru yakni peren- canaan belajar, pengorganisasian, pelaksanaan dan evaluasi proses dan hasil belajar. Secara rinci hasil dan kajian aspek-aspek tersebut diuraikan sebagai berikut:

\section{Case 1: Perencanaan Pembelajaran (Planning)}

Hasil wawancara dan amatan di kelas 2A, 2B dan 2C, pada aspek perencanaan guru melakukan persiapan yang tergambar dari dokumen Rencana Pelaksanaan Pembelajaran (RPP), Silabus dan tersedianya media belajar yang dirancang oleh guru. Misalnya, di kelas 2A, 2B, 2C pada mata pelajaran seni, budaya dan kesenian (SBK), terkait pengajaran musik guru berkolaborasi dengan guru lain yang paham dan pandai menggunakan dan memiliki kemampuan untuk mengajari musik. Dalam proses pembelajaran guru tidak selalu menyediakan atau menggunakan media untuk semua topik yang diajarkan. Dalam proses belajar sehari-hari buku paket yang dimiliki guru dan siswa adalah media belajar yang paling diandalkan dalam proses belajar. Dalam penyusunan RPP baik guru kelas 2A, 2B dan $2 \mathrm{C}$ melakukan penyiapan rencana pembelajaran secara mandiri (sendiri). Kadangkadang mereka melakukan penyiapan atau perencaan pembelajaan (RPP) secara kolaborasi khususnya pada mata pelajaran atau meteri yang membutuhkan keahlian khusus seperti musik, atau seni tari dan lagu. Umumnya aspek-aspek seni dan lagu atau keterampilan musik, drum band difokuskan pada kegiatan ekstrakurikuler. Guru kelas umumnya mengajari hampir semua mata pelajaran sehingga menuntut tingkat kreativitas dan tanggujawab yang lebih. Untuk Program semester dan tahunan dibicarakan secara bersama-sama oleh guru dan kepala sekolah dalam rapat dewan guru atau bersama pihak yayasan.

Skenario belajar dalam RPP yang dirancang sesuai pedoman kurikulum KTSP. Persiapan kelas di kelas 2A, 2B, 2C umumnya homogen atau mirip. Biasanya para guru menuntun anak-anak berbaris dan memberi salam kepada guru. Setelah masuk kelas berdoa bersama, mengambil presensi, mengatur posisi duduk dengan pola formasi huruf $\mathrm{O}$, U dan T. Kadang diselingi de- 
ngan kegiatan literasi, membaca, dan sesi tanya jawab tentang cerita yang baru dibaca atau diperdengarkan, ataupun terkait materi pelajaran yang telah dipelajari sehari sebelumnya. Guru kemudian menjelaskan tujuan pelajaran dan aktivitas atau kegiatan belajar yang akan dilakukan pada mata pelajaran itu. Rata-rata jadwal belajar di kelas dua sebanyak dua atau tiga mata pelajaran. Sebelum memulai pelajaran semua siswa kelas dua diwajibkan membaca kegiatan membaca di kelas dua adalah sebuah keharusan karena bertujuan memperlancar kemampuan membaca yang sudah mulai dimiliki oleh siswa kelas dua. Secara ringkas tahapan persiapan manajemen kelas guru tergambar pada Tabel 1.

Bila ada kebutuhan alat peraga misalnya dalam topik pertumbuhan tanaman, konsep waktu skenario belajar diubah dengan melakukan pengamatan tanaman di luar kelas, khususnya di sekitar sekolah untuk mengamati tumbuhan atau. Dalam wawancara guru kelas 2C menjelaskan bahwa "siswa dibagi dalam kelompok kecil 4-5 orang untuk melakukan pengamatan dan mencatat perubahan dan pertumbuhan kacang ijo yang direndam dalam air sampai muncul kecambah." Alat peraga lain seperti jam dinding untuk menjelaskan konsep waktu, jam, menit dan detik. Dalam mata pelajaran Pendidikan Lingkungan Hidup (PLH). Guru kelas 2B menjelaskan bahwa "siswa membawa daun kelapa dan membuat sapu lidi." Metode dan media semacam ini dipilih guru karena diyakini memiliki banyak tujuan dan memudahkan belajar siswa karena belajar dengan pengalaman dan pengamatan langsung. Skenario belajar dikreasi guru untuk menjangkau kebutuhan belajar siswa yang beragam dan bertolak dari pengalaman nyata.

\section{Case 2: Pengorganisasian Pembelajaran}

Pengorganisasian belajar yang dilakukan guru di kelas 2A, 2B, dan 2C umumnya hampir sama karena disepakati bersama-sama dalam mengkonsepkan pola dan dinamika kelas. Umumnya pola duduk siswa satu arah, namun kadang divariasikan,dengan mengorganisasi perilaku siswa dan kegiatan belajar agar lebih variatif dan tidak membosankan dengan mengatur pola duduk berbentuk lingkaran, berbentuk huruf $\mathrm{U}, \mathrm{O}$, $\mathrm{C}$ atau huruf T. Guru kelas 2A menjelaskan bahwa "penggorganisasian tempat duduk misalnya diatur dengan mempertimbangkan karakter, postur kecil dan besar, tinggi rendah, aktif dan kurang aktif, suka ngomong dan pendiam." Hal ini bertujuan untuk mengurangi perilaku bias siswa yang umumnya suka bercerita, menoleh kiri, kanan, atau berbicara dengan kawan-kawannya yang duduk bersebelahan di kiri kanan atauyang duduk di depan atau belakang meja. Rangkuman secara umum tergambar dalam Tabel 2.

\section{Tabel 1. Kondisi dan Tindakan Perencanaan Guru Kelas}

\begin{tabular}{|c|c|c|}
\hline Manajemen Kelas & Tindakan & Hasil \\
\hline $\begin{array}{l}\text { Persiapan sebelum proses } \\
\text { Pembelajaran }\end{array}$ & $\begin{array}{l}\text { Guru merinci kondisi dan keadaaan } \\
\text { kelas yang sesuai dengan metode } \\
\text { pembelajaran }\end{array}$ & $\begin{array}{l}\text { Perencanaannnya yang baik: ada } \\
\text { materi, media, posisi duduk siswa } \\
\text { diatur dengan pola huruf } \mathrm{O}, \mathrm{U}, \mathrm{T} \text {. }\end{array}$ \\
\hline Proses Persiapan & $\begin{array}{l}\text { Menentukan dan memilih metode } \\
\text { dan media pembelajaran yang cocok } \\
\text { sesuai topi seperti metode diskusi, } \\
\text { out door. Menggunakan media } \\
\text { seperti Jam Dinding atau Daun } \\
\text { Kelapa untuk mengajari keterampilan } \\
\text { anak dalam menganyam ketupat atau } \\
\text { membuat janur }\end{array}$ & $\begin{array}{l}\text { Baik: Umumnya memilih metode } \\
\text { ceramah, ada pengamatan langsung } \\
\text { dan kerja kelompok }\end{array}$ \\
\hline Penyusunan Perencanaan & $\begin{array}{l}\text { Membuat Silabus, RPP, bahan ajar } \\
\text { umumnya secara pribadi }\end{array}$ & $\begin{array}{l}\text { Baik: Sesuai panduan dinas } \\
\text { pendidikan dan tuntutan } \\
\text { kurikulum }\end{array}$ \\
\hline Keterlibatan pihak lain & $\begin{array}{l}\text { Sewaktu-waktu koordinasi dengan } \\
\text { guru lain }\end{array}$ & $\begin{array}{l}\text { Masih kurang, tergantung } \\
\text { kebutuhan,belum kolaboratif }\end{array}$ \\
\hline
\end{tabular}


Tabel 2. Pengorganisasian Pembelajaran Guru

\begin{tabular}{|c|c|c|}
\hline Kebutuhan & Tindakan & Hasil \\
\hline $\begin{array}{l}\text { Persiapan } \\
\text { pengorganisasian }\end{array}$ & $\begin{array}{l}\text { Presensi dan mengatur atau merotasi tempat } \\
\text { duduk }\end{array}$ & Baik, rutin sesuai kebutuhan \\
\hline $\begin{array}{l}\text { Pola penempatan } \\
\text { siswa dalam } \\
\text { kegiatan belajar }\end{array}$ & $\begin{array}{l}\text { Mengatur dinamika kelompok, sesuai tema dan } \\
\text { karakteristik siswa dengan formasi duduk } \\
\text { berbentuk lingkaran, huruf U atau huruf T, huruf } \\
\mathrm{C} \text {, huruf O }\end{array}$ & $\begin{array}{l}\text { Baik, menerapan metode out } \\
\text { door }\end{array}$ \\
\hline $\begin{array}{l}\text { Pelibatan orang lain } \\
\text { dalam } \\
\text { pegorganisasian }\end{array}$ & $\begin{array}{l}\text { Proses mengajar dilakukan secara individu oleh } \\
\text { guru dengan koordinasi dengan orangtua dalam } \\
\text { hal proses adaptasi dan tahapan mandiri }\end{array}$ & $\begin{array}{l}\text { Belum kolaboratif tetapi } \\
\text { lebih koordinatif antara guru } \\
\text { dan orangtua siswa }\end{array}$ \\
\hline $\begin{array}{l}\text { Mengorganisir } \\
\text { kegiatan belajar }\end{array}$ & $\begin{array}{l}\text { Mengatur ketertiban dan keteraturan tempat } \\
\text { duduk }\end{array}$ & $\begin{array}{l}\text { Baik, siswa tertib dalam } \\
\text { belajar }\end{array}$ \\
\hline
\end{tabular}

Ketiga guru menjelaskan bahwa pengaturan semacam ini dikoordinasi dengan pihak orang tua karena ada hal yang terkait dengan masalah anak-anak yang bermasalah dengan penglihatan, berkacamata, siswa yang memiliki masalah pendengaran dan perilaku hiper aktif dari siswa tertentu. Dalam organisasi pembelajaran setelah proses persiapan awal, berbaris dan masuk kelas, dan berdoa guru melakukan presensi, mengecek posisi duduk, mengatur tempat duduk kembali, merotasi sesuai kebutuhan belajar sesuai tema dan kegiatan yang dilakukan pada hari itu. Pengorganisasian ini memperhatikan tingkat perkembangan anak baik pada aspek kemampuan, minat, bakat, tingkat kemampuan dan kecepatan dalam penguasaan pengetahuan, komunikasi bahasa, tingkat kemandirian dan kemampuan adaptasi dengan materi, metode dan proses pembelajaran pada semua mata pelajaran.

Case 3: Implementasi atau Pelaksanaan Pembelajaran

Implementasi manajemen kelas pada tahap proses pelaksanaan pembelajaran yang dilakukan guru di kelas 2A misalnya memulainya dengan menyepakati tata tertib, disiplin diri, kebersihan dan kerapihan kelas keteraturan, menjaga ketenangan dan membangun sikap hormat terhadap guru dan teman. Perilaku bias yang dominan di kelas rendah seperti siswa kelas dua terjadi ketika beberapa siswa sudah menyelesaikan tugasnya sementara siswa lain belum menyelesaikan pekerjaan mereka. Karena itu dalam pelaksanaan pembelajaran guru harus mampu menciptakan manajemen pengorganisasian kelas dan kegiatan belajar sehingga ia juga bisa mampu mengendalikan perilaku siswa. Tujuannya agar kondisi dan suasana belajar menjadi nyaman, seluruh siswa bisa dengan senang untuk belajar, mereka semangat dan gembira dalam melakukan semua aktivitas belajar selama proses belajar berlangsung. Secara keseluruhan gambaran umum implementasi pembelajaran terlihat dalam Tabel 3.

\section{Case 4: Evaluasi Belajar}

Dalam tahapan evaluasi pembelajaran di kelas oleh guru di SD Panca Setya 2 pertama-tama dimulai dari pihak guru sendiri terkait kinerja guru sendiri. Kinerja guru dievaluasi melalui supervisi kelas terkait adminstrasi kelas, inventaris kelas, perangkat pembelajaran terkait RPP, Silabus, program tahunan (prota) dan program semester (promes) untuk lingkup interen sekolah maupun oleh pihak dinas pendidikan terutama dalam mempersiapkan akreditasi sekolah.

Evaluasi untuk siswa, mencakup empat indikator kegiatan penilaian yaitu kegiatan evaluasi itu sendiri berupa mengamati, memberi nilai terhadap aktivitas belajar siswa pada ranah konitif, afektif dan psikomotor. Secara umum gambaran evaluasi tergambar pada Tabel 4 . 
Tabel 3. Pelaksanaan Pembelajaran

\begin{tabular}{|c|c|c|}
\hline $\begin{array}{l}\text { Kebutuhan } \\
\text { Belajar }\end{array}$ & Tindakan & Hasil \\
\hline $\begin{array}{l}\text { Mengendalikan } \\
\text { perilaku siswa }\end{array}$ & $\begin{array}{l}\text { Menerapkan disiplin diri, tepat waktu, } \\
\text { duduk tertib dan tenang, bersikap serius } \\
\text { dan tanggungjawab, mewarnai gambar, } \\
\text { menulis tegak bersambung bagi yang } \\
\text { sudah menyelesaikan tugasnya, berlaku } \\
\text { humanis, sabar dan tetap murah } \\
\text { senyum }\end{array}$ & $\begin{array}{l}\text { Baik, kelas terkendali, ada keributan atau } \\
\text { keramaian kecil selama belajar diatasi } \\
\text { dengan aktivitas edukatif lainnya seperti } \\
\text { mewarnai gambar dan menulis tegak } \\
\text { bersambung, atau menambah soal. }\end{array}$ \\
\hline $\begin{array}{l}\text { Menciptakan } \\
\text { kondisi dan } \\
\text { suasana belajar }\end{array}$ & $\begin{array}{l}\text { Memberi tugas secara sistematis dan } \\
\text { terstruktur dengan tambahan soal, } \\
\text { pembinaan rohani pada setiap jumat } \\
\text { dengan tradisi katolik, misa bulanan }\end{array}$ & $\begin{array}{l}\text { Baik, siswa tenag dan serius mengikuti } \\
\text { proses belajar dan mengerjakan PR } \\
\text { dengan baik. Melaksanakan kesepakatan } \\
\text { reward dan sangsi bersama-sama }\end{array}$ \\
\hline $\begin{array}{l}\text { Pengembangan } \\
\text { minat dan } \\
\text { kreativitas siswa }\end{array}$ & $\begin{array}{l}\text { Guru memberi motivasi,pujian, } \\
\text { bimbingan individual,kelompok seperti } \\
\text { koor, musik dan olahraga setiap hari } \\
\text { Kamis, mendekorasi ruang kelas } \\
\text { bersama siswa }\end{array}$ & $\begin{array}{l}\text { Baik, Siswa cukup kreatif dan semangat } \\
\text { berolahraga sesuai hobi, basket, bola, } \\
\text { musik, koor sehingga guru hanya } \\
\text { mengorganisasi siswa di lapangan }\end{array}$ \\
\hline $\begin{array}{l}\text { Penggunaan } \\
\text { metode dan media } \\
\text { yang relavan }\end{array}$ & $\begin{array}{l}\text { Metode ceramah dan out door, dan } \\
\text { media yang ada sekitar rumah dan } \\
\text { sekolah (jam dinding, kacang ijo, daun } \\
\text { kelapa) }\end{array}$ & $\begin{array}{l}\text { Cukup inovatif, tidak banyak kegiatan } \\
\text { belajar yang didokumentasi dan disimpan } \\
\text { dengan baik }\end{array}$ \\
\hline $\begin{array}{l}\text { Penerapan metode } \\
\text { yang sesuai atau } \\
\text { cocok }\end{array}$ & $\begin{array}{l}\text { Metode ceramah dengan bantuan } \\
\text { media, kadang-kadang melalui kerja } \\
\text { kelompok }\end{array}$ & $\begin{array}{l}\text { Sudah koordinasi namun belum } \\
\text { kolaboratif }\end{array}$ \\
\hline $\begin{array}{l}\text { Pemahaman } \\
\text { masalah siswa } \\
\text { secara individual } \\
\text { dan kelompok }\end{array}$ & $\begin{array}{l}\text { Tidak diskriminatif dan lebih prioritas } \\
\text { bagi siswa yang memiliki problem pada } \\
\text { perilaku dan kemampuan memahami } \\
\text { materi }\end{array}$ & $\begin{array}{l}\text { Realisasi program bimbingan } \\
\text { individual/kelompok, program atau } \\
\text { remdial. Memberi reward kepada yang } \\
\text { rajin, berani, displin berupa alat tulis }\end{array}$ \\
\hline
\end{tabular}

Tabel 4. Evaluasi Belajar Mengajar

\begin{tabular}{|c|c|c|}
\hline Kebutuhan Belajar & Tindakan & Hasil \\
\hline $\begin{array}{l}\text { Evaluasi terhadap } \\
\text { proses belajar } \\
\text { mengajar }\end{array}$ & $\begin{array}{l}\text { Melakukan amatan, penilaian dan } \\
\text { koreksi terhadap catatan, PR dan hasil } \\
\text { tes siswa }\end{array}$ & $\begin{array}{l}\text { Baik, ada cataran harian, program } \\
\text { remidial }\end{array}$ \\
\hline Tujuan Evaluasi & $\begin{array}{l}\text { Acuan untuk melihat hasil dan prestasi } \\
\text { siswa pada tiga bulan, satu semester dan } \\
\text { satu tahun pelajaran untuk kenaikan } \\
\text { kelas }\end{array}$ & $\begin{array}{l}\text { Acuan perbaikan utuk tatap muka } \\
\text { berikutnya, midsemester dan ujian } \\
\text { semester, evaluasi program sekolah }\end{array}$ \\
\hline $\begin{array}{l}\text { Tindakan terhadap } \\
\text { hasil evaluasi }\end{array}$ & $\begin{array}{l}\text { Membagi nilai murni Mid semester, } \\
\text { kordinasi dengan orangtua untuk } \\
\text { program remidial }\end{array}$ & $\begin{array}{l}\text { Ada perbaikan hasil, program les } \\
\text { tambahan di luar jam sekolah oleh } \\
\text { orangtua }\end{array}$ \\
\hline $\begin{array}{l}\text { Evaluasi } \\
\text { pimpinan/pengawas }\end{array}$ & $\begin{array}{l}\text { Laporan semester, visitasi pengawas dan } \\
\text { kepala sekolah }\end{array}$ & $\begin{array}{l}\text { Program perbaikan dan tambahan } \\
\text { fasilitas }\end{array}$ \\
\hline
\end{tabular}

\section{Case 5. Respon Siswa}

Penerapan manajemen kelas oleh guru kelas 2A, 2B, 2C di SD Panca Setya 2 Sintang terkait empat aspek dalam manajemen kelas. Keempat aspek tersebut adalah manajemen perencanaan, pengorganisasian, pe- laksanaan dan evaluasi. Dari angket respon siswa dengan 15 indikator pertanyaan seperti tergambar pada Tabel 5 dihitung dengan skor respon jawaban ya (skor 1) dan tidak (skor 0). Jadi skor total tiap item adalah 64 sesuai jumlah responden yang 
mengisi angket. Rerata aspek dihitung berdasarkan perolehan skor dibagi jumlah responden dan dikali $100 \%$. Skala penilaian menggunakan kriteria penilaian sebagai berikut: $\geq 85-100 \%$ (sangat baik) $\geq 75-84 \%$ (baik) $\geq 65-74 \%$ (cukup baik) sedangkan $\leq$ $64 \%$ kurang.

Dari hasil pengolahan angket respon siswa diperoleh gambaran tingkat respon siswa terhadap pelaksanaan manajemen kelas oleh guru pada ketiga kelas amatan adalah sebagai berikut:

\section{Tabel 5. Respon siswa}

\begin{tabular}{|c|c|c|}
\hline Aspek praksis manajemen kelas & Skor & Ket \\
\hline $\begin{array}{l}\text { Menyiapkan pengajaran, } \\
\text { menginformasikan jadwal \& topik } \\
\text { setiap tatap muka dgn baik }\end{array}$ & \multirow[t]{3}{*}{51} & \multirow[t]{2}{*}{$\mathrm{R}$} \\
\hline Selalu hadir disiplin dan tepat waktu & & \\
\hline $\begin{array}{l}\text { Mengatur dan mengubah tempat } \\
\text { duduk }\end{array}$ & & \multirow{3}{*}{$\mathrm{O}$} \\
\hline $\begin{array}{l}\text { Merapihkan meja, kursi, pakaian } \\
\text { sebelum \& setelah belajar }\end{array}$ & \multirow[t]{2}{*}{53} & \\
\hline $\begin{array}{l}\text { Menyiapkan alat tulis menulis, alat } \\
\text { peraga, media }\end{array}$ & & \\
\hline $\begin{array}{l}\text { Disiplin, bersikap adil, ramah dan } \\
\text { menyenangkan }\end{array}$ & \multirow{6}{*}{54} & \multirow{6}{*}{$\mathrm{I}$} \\
\hline $\begin{array}{l}\text { Menenangkan siswa dengan kode- } \\
\text { kode/trik }\end{array}$ & & \\
\hline $\begin{array}{l}\text { Menghukum yang tidak disiplin } \\
\text { Memberi hadiah dan pujian }\end{array}$ & & \\
\hline $\begin{array}{l}\text { Menulis atau mendikte secara lisan dan } \\
\text { tulisan }\end{array}$ & & \\
\hline Belajar secara individual dan kelompok & & \\
\hline Belajar di luar kelas (out door) & & \\
\hline $\begin{array}{l}\text { Memberi tes, mengoreksi dan memberi } \\
\text { nilai }\end{array}$ & \multirow{2}{*}{52} & \multirow{2}{*}{$\mathrm{E}$} \\
\hline $\begin{array}{l}\text { Kepala sekolah/pengawas supervisi di } \\
\text { kelas }\end{array}$ & & \\
\hline Ket. Skor mutlak: Ya (1) Tidak (0) & \multicolumn{2}{|c|}{$N=64$} \\
\hline$R=$ rencana,$O=$ organisasi $I=$ implementas & $E=e v$ & uasi \\
\hline
\end{tabular}

Dari hasil angket siswa terhadap 15 item yang menggambarkan empat aspek manajemen kelas diperoleh tingkat kepuasan siswa terhadap penerapan manajemen kelas oleh guru sebesar $80-84 \%$ pada keempat aspek manajemen kelas yang diterapkan guru dalam proses pembelajaaran. Kondisi ini tergambar melalui grafik poligon Gambar 1.

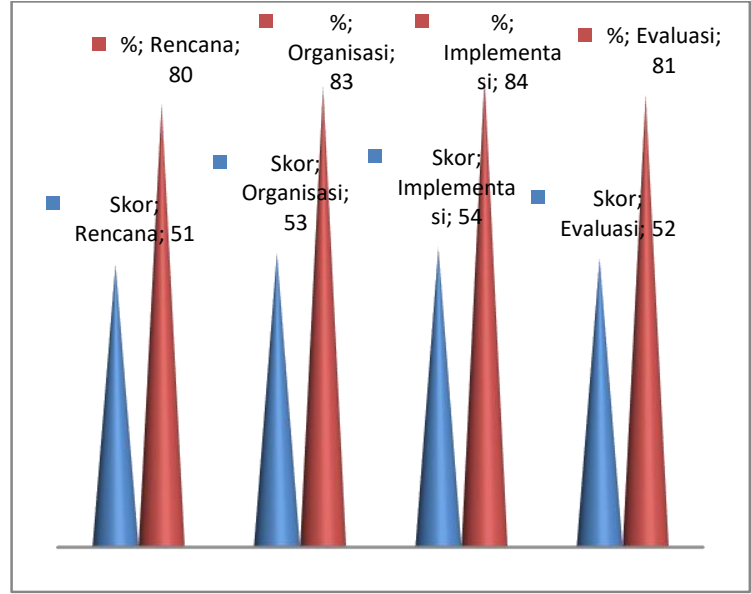

Gambar 1. Respon Siswa terhadap Pelaksanaan Manajemen Kelas oleh Guru

Dari persentasi yang ditunjukkan oleh diagram poligon pada gambar 1 tergambar bahwa tingkat kepuasan atau repon positif siswa terhadap guru pada aspek perencanaan belajar sebesar $80 \%$. Artinya, ada 51 siswa dari 64 siswa merasakan bahwa guru melakukan persiapan belajar mengajar secara baik. Sebaliknya ada 13 siswa dari 64 siswa menjawab tidak, atau setidaknya memberi repon negatif. Artinya ada 20\% siswa memberi catatan pada guru bahwa siswa membutuhkan perencanaan belajar yang lebih baik lagi untuk memenuhi harapan mereka dalam belajar. Pada aspek pengorganisasian belajar ada 53 siswa dari 64 siswa memberi respon positif, atau sebesar $83 \%$ siswa merasakan bahwa guru melakukan pengorganisasian belajar dengan baik. Sebaliknya, ada 11 siswa memberi respon sebaliknya, artinya ada $17 \%$ siswa menghendaki perbaikan cara guru dalam mengorganisasi pembelajaran. Pada aspek implementasi pembelajaran ada 54 siswa memberi respon positif. Artinya, ada $84 \%$ siswa mengalami bahwa guru melakukan penerapan atau impelementasi pembelajaran dengan baik. Disisi penggorganisasian belajar sekitar $16 \%$ siswa menghendapi perbaikan cara-cara guru dalam menerapkan strategi disiplin, guru harus lebih baik lagi dalam mendikte secara lisan maupun tulisan, serta melakukan variasi pembelajaran dengan meningkatkan aktivitas di luar kelas. Pada segi evaluasi pembelajaran dari 
64 siswa yang mengisi angket ada 52 siswa yang memberi respon positif. Artinya, ada $83 \%$ siswa yang merasa puas dengan penilaian yang dilakukan guru. Sebaliknya ada 13 siswa atau sebesar $17 \%$ siswa menghendaki beberapa perbaikan pada aspek penilaian guru seperti cara memberi tugas atau tes, juga memeriksa dan memberi nilai kepada siswa. Penilaian yang obyektif dari guru perlu ditingkatkan seperti membagi hasi tes, dan memberi catatan koreksi pada jawaban yang belum tepat dan juga memberi motivasi dan pujian untuk meningkatkan semangat dan daya juang serta disiplin siswa dalam belajar dan mempersiapkan ujian atau ulangan harian.

Dari hasil respon siswa tergambar bahwa pada semua aspek manajemen kelas oleh guru rerata semua aspek rata-rata berkisar dari $80-84 \%$. Artinya sesuai skala penilaian berada pada kategori baik. Pada dimensi ini sebenarnya sangat terlihat bahwa manajemen kelas yang dilakukan oleh guru cukup standar, artinya belum masuk kategori sangat bagus, atau masih kurang. Kondisi ini yang perlu disadari guru bahwa pentingnya guru melakukan inovasi, artinya dibutuhkan keberanian untuk keluar dari zona aman guru dalam pengajaran di kelas.

\section{Pembahasan}

Terkait manajemen kelas untuk proses belajar sukses dengan mutu dan manfaat belajar yang terukur maka beberapa hal yang perlu dikaji dari unsur-unsur manajemen kelas:

\section{Manajemen Perencanaan Belajar Guru}

Motivasi dan niat untuk menciptakan rencana dan tujuan belajar yang berkualitas adalah langkah awal dari perencanaan belajar sukses. Niat dan motivasi akan mengarahkan tindakan belajar guru yang akan dikerjakan bersama siswa. Motivasi dan niat baik guru akan melahirkan tindakan inovatif dalam skenario belajar guru, dengan demikian guru berpikir untuk menyertakan elemen-elemen penting dalam tahap perencanaan belajar. Hal ini perlu dan penting bagi guru sehingga mencegah model perenca- naan plagiasi yang umumnya jadi fenomena dalam administrasi RPP guru. Benar bahwa ada model ATM (ambil, tiru, modifikasi) namun bobot model ini akan bermutu jika guru sendiri memiliki motivasi dan niat baik untuk menyusun rencana pembelajaran dengan orientasi membangun kreativitas dan solusi menuju pengembangan kapasitas profesionalitasnya. Artinya, setiap perencanaan pembelajaran selalu disertai dan bermula dengan tindakan dan tujuan strategis.

Dalam penyusunan rencana belajar guru sebisa mungkin menghindari frasa "anak belajar tentang apa, atau siswa akan mengerti atau tidak pengetahuan yang ia ajarkan. Guru diminta untuk fokus pada kata kerja tindakan (action strategis) sehingga anakanak dapat berimprovisasi dan berkreasi untuk melakukan sesuatu (Stronge, 2019, p. 2). Penciptaan lingkungan kelas yang kondusif dan sehat akan membantu menciptakan proses kreatif. Teori ekologi menjelaskan bahwa proses belajar siswa terjadi di dalam lingkungan sosial, seperti keluarga atau ruang kelas. Jadi interaksi yang dimiliki dan terjadi pada diri anak-anak dalam lingkungan sekolah dan kelas adalah proses proksimal dan dianggap sebagai mekanisme penting yang menghasilkan perkembangan manusia (Bronfenbrenner, \& Morris, 2006, p. 795; Hendrickx, Mainhard, Boor-klip, Cillessen, \& Brekelmans, 2016, p. 31). Dengan demikian fokus guru dalam proses perencanaan belajar adalah menciptakan tindakan dan strategi di kelas (the actions and strategies) untuk memecahkan masalah belajar untuk mencapai kebermanfaatan atau kepuasan siswa dalam belajar (Doyle, 1986, p. 397).

\section{Manajemen Pengorganisasian Belajar}

Tanpa guru sadari managemen pengorganisasian belajar sangat mempengaruhi elemen fisik kelas. Pengorganisasian pembelajaran juga sangat terkait dengan aktivitas mengenai bagaimana penataan posisi duduk yang membuat siswa nyaman dalam proses belajar. Juga, terkait bagaimana menata dan menempatkan lemari, atau artefak, hiasan dinding, letak spidol dan kapur tulis, presensi kelas, penempelan gambar atau 
bingkai foto maupun portofolio siswa sehingga ruang kelas bisa menjadi interaktif serta produktif dalam proses belajar. Infrastruktur kelas harus ditata tidak saja secara fisik tetapi juga psikis terutama mengorganisasi perilaku dan karakter pribadi setiap anak.

Guru efektif dan inovatif menghiasi ruangan kelas dengan pekerjaan siswa, mengatur dan menata furnitur untuk mempromosikan interaksi yang sesuai sehingga siswa sendiri juga akan memiliki area yang nyaman untuk bekerja dan belajar (Stronge, 2019, p. 3). Guru juga harus mempertimbangkan kebutuhan siswa yang beragam dalam mengatur kelas dengan menyisakan ruang bagi siswa berkebutuhan khusus atau cacat fisik seperti menggunakan kursi roda untuk bergerak secara leluasa. Ruang kelas harus ditata dengan jarak meja untuk jalan setapak sehingga siswa memiliki akses yang baik seperti mengambil bahan, atau membuang sampah. Hal ini menyebabkan peluang yang kecil untuk menciptakan gangguan bagi siswa yang lainnya dalam belajar. Pengorganisasian kelas dan pembelaajran semacam ini penting agar memungkinkan guru untuk bergerak bebas di kelas memantau kemajuan belajar siswa karena lingkungan fisik memberi dan mengundang berbagai jenis pembelajaran, dan berkontribusi dalam membangun sikap yang berbeda dari setiap siswa terhadap pembelajaran (Claxton, 2014, p. 38). Jadi dalam penggorganisasian belajar guru harus sungguhsungguh memerankan fungsi sebagai pengamat perilaku siswa sehingga ia bisa membaca dinamika dan ritme belajar setiap anak. Hal ini penting karena perilaku yang berbeda dari setiap anak membutuhkan tindakan atau pendekatan yang berbeda. Demikian juga dinamika, suasana dan ritme atau kecepatan belajar yang berbeda-beda dari tiap siswa akan menentukan strategi tindakan yang berbeda dalam manajemen kelas. Dengan demikian guru di sekolah dasar dituntut memiliki kapasitas atau keahlian managerial dalam memperhatikan detail-detail kecil untuk meningkatkan efektivitas penggunaan ruang kelas sehingga siswa bisa memperoleh manfaat (benefits) dari proses belajar itu sendiri.

Inti dari organisasi belajar adalah bagaimana membuat kualitas manajemen ruang kelas dan organisasi bisa terintegrasi. Organisasi kelas berperan menangkap aspek struktural bagaimana seorang guru menyusun ruang kelasnya, dan harapannya untuk perilaku siswa sesuai keyakinan interpersonal guru dan tanggungjawab guru menetapkan norma-norma (Stronge, Tucker, \& Hindman, 2019, p. 4). Elemen-elemen struktural dan interpersonal tersebut berkontribusi terhadap manajemen kelas secara keseluruhan sehingga menciptakan iklim dan budaya unik setiap kelas sebagai episentrum belajar.

\section{Manajemen Implementasi Belajar}

Dalam mensukseskan tahapan pelaksanaan belajar maka guru perlu mengaktifkan peran dari aturan-aturan (rules) kelas untuk membentuk iklim belajar dan mendukung efektivitas belajar sehingga mencegah perilaku-perilaku bias. Untuk mewujudkan karakter perilaku yang mencerminkan kelas yang baik siswa harus mengembangkan sikap saling menghormati (respect for others), partisipatif, rasa memiliki (sense of beloging) dan disiplin. Bila ada siswa membuat sesuatu menjadi berantakan ma$\mathrm{ka}$ ia bertangungjawab untuk membereskannya. Para siswa tidak boleh berlari dan memukul-mukul meja dan bangku. Mereka juga tidak boleh makan, mengunyah permen di dalam ruangan. Beberapa contoh aturan penting dan wajib ini perlu ditanamkan sebagai nilai disiplin. Siswa perlu dilatih secara rutin oleh guru dengan pendekatan, cara-cara yang yang humanis, bersahabat dan edukatif.

Membangun karakter perilaku belajar tidak cukup guru hanya menegur secara masal atau memberitahu dari meja guru di depan kelas tetapi guru perlu menerapkan pendekatan personal, kelompok secara rutin untuk menerapkan aturan-aturan tersebut dalam implementasi pembelajaran di kelas. Dimensi penataan karakter perilaku kelas akan sangat membantu pelaksanaan dalam proses pembelajaran. 


\section{Manajemen Evaluasi Belajar}

Terkait mutu proses belajar di kelas yang sukses dan berhasil DaLone dan McLean menawarkan pola-pola manajemen kelas yang dapat dikembangkan guru dalam proses belajar mengajar di kelas dan dalam keseluruhan praktik pendidikan di sekolah dasar (Ozkan, 2015, p. 5). Beberapa aspek belajar sukses adalah mutu informasi dan pengetahuan yang disampaikan guru, kualitas sistem mutu, dan mutu layanan yang berpengaruh terhadap subjek belajar (pembelajar) yang bermuara pada kepuasan belajar dan manfaat atau kegunaan dari proses belajar yang dilakukan setiap hari di kelas. Hal ini tercermin pada bagan manajemen mutu di bawah ini.

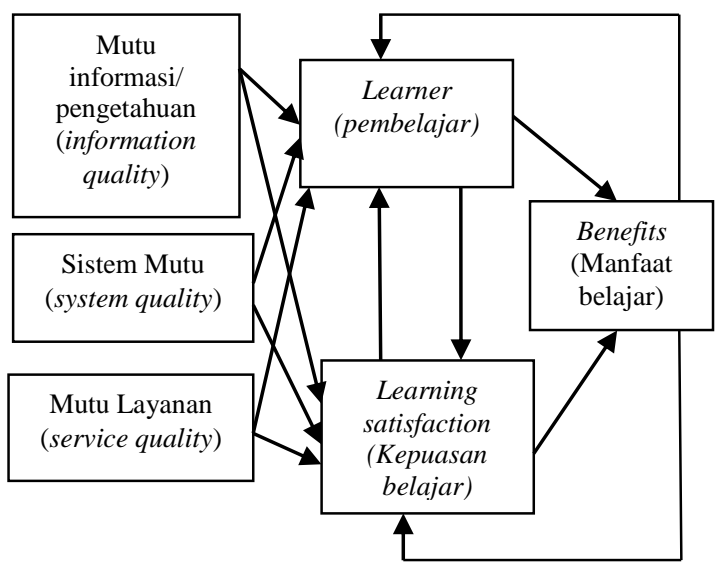

Gambar 2. Manajemen Mutu Belajar Sukses, Adaptasi Model DaLone dan McLean, 2003 (Lee-post, 2009, pp. 62-63; Ozkan, 2015, p. 5)

Element mutu yang dimaksud adalah: Pertama, adalah terkait dengan mutu informasi atau pengetahuan yang diajarkan guru kepada siswa, apakah pengetahuan dan informasi itu sungguh penting, baru (up date) dan berdampak pada perluasan pengetahuan dan kemampuan kognitif dan akademik siswa secara luas dan bermakna. Kedua adalah sistem mutu terkait kualitas proses dan hasil belajar yang dimiliki sekolah, sistem layanan apakah tersedia dengan baik dan dilayani dengan mudah dan cepat. Lingkungan kelas dan sekolah yang aman, bersahabat jauh dari kebisingan, bahaya atau bencana yang sifatnya musiman seperti banjir yang selalu datang menimpa seko- lah seperti pengalaman beberapa sekolah di Sintang seperti SDN 23 Menyumbung, Sintang. Proses pendidikan dan organisasi sekolah, guru dan pegawai dikelola dengan baik dan profesional terkait kesejahteraan guru dan pegawai, kelengkapan fasilitas belajar, ketersediaan media. Karena pada dasarnya guru dan siswa adalah pengguna sekaligus pembelajar (user dan leaner). Pengguna dan pembelajar harus memiliki kondisi dan situasi terpuaskan dari sisi daya dukung manajemen mutu sehingga proses belajar yang dilaksanakan sungguh-sungguh memberi manfaat yang besar kepada setiap anak dan guru sendiri dalam pengembangan keprofesiannya secara berkelanjutan.

Daya dukung elemen atau infrastuktur kelas secara sederhana bisa terlihat pada kemampuan lingkungan sekolah dan ruang kelas dalam menyediakan berbagai fasilitas belajar dan sumber-sumber pengetahuan baik dalam bentuk gambar mapun dalam bentuk tulisan, pamlet, banner, media film, gambar, alat peraga yang sesuai dengan materi ajar, usia, jenis kelamin, hobi, minat, bakat dan berbagai kebutuhan bermain sambil belajar dan belajar sambil bermain anak-anak usia sekolah dasar.

Konfigurasi ruang kelas, penataan kursi meja di kelas harus menciptakan dan memberi impresi kuat bagi anak-anak untuk belajar secara menyenangkan. Infrastuktur kelas dan infrastruktur teknologi menjadi penting dalam menciptakan dan membuat siswa memiliki perasaan bebas, tidak takut atau tertekan baik oleh sikap guru maupun sesama temannya. Proses belajar yang dilakukan harus bermuara pada kepuasan subjek. Artinya siswa harus bisa menemukan dan merasakan manfaat serta keuntungan bagi pengembangan pengetahuan, kepribadian, dan keterampilan mereka dalam mempersiapkan masa depannya secara lebih sukses.

Implementasi manajemen kelas yang sukses bisa diraih dengan baik dan berkesinambungan jika guru memahami secara teoretis dan praktis enam unsur manajemen kelas dalam proses belajar maupun dalam konteks manajemen sekolah yang lebih luas dan holistik dalam proses pendidikan di 
sekolah dasar terutama untuk meraih pendidikan dan prospek hasil belajar masa depan di era pendidikan moderen saat ini. Beberapa penemuan manajemen belajar seperti sistem HELAM (Hexagonal e-Learning Assesment) bisa dielaborasi dan diadopsi untuk mengembangkan model managemen kelas yang lebih sukses seperti hexagonal learning yang digagas oleh para ahli yang mengembangkan teori hexagonal (Lee-post, 2009, p. 63; Ozkan, 2015, p. 77).

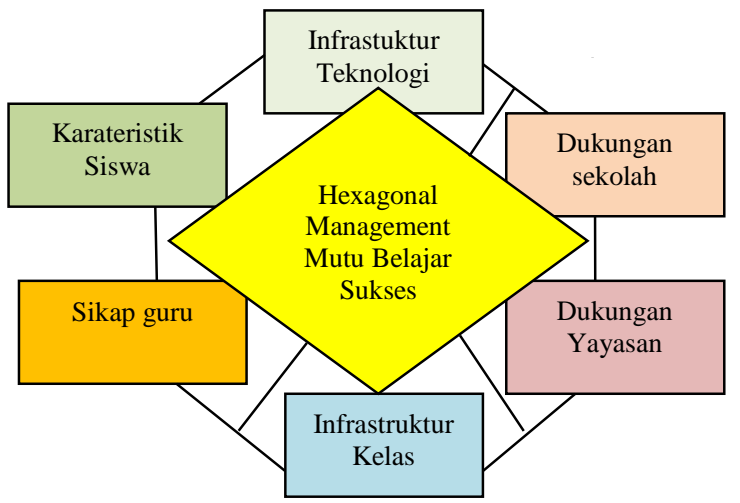

Gambar 3. Bagan Hexagonal Manajemen Kelas untuk Pembelajaran

Sukses di Kelas-Kelas Sekolah

Dasar. Adaptasi Konsep HELAM (Ozkan, 2015,p.26).

Sejalan dengan teori hexagonal of learning minimal ada enam aspek penting yang semestinya diperhatikan dalam proses belajar di sekolah dasar yakni karakteristik siswa, sikap guru, infrastruktur kelas, infrastruktur teknologi, daya dukung sekolah dan daya dukung lembaga maupun pemerintah. Keenam aspek ini harus benar-benar diperhatikan dalam manajemen pembelajaran guru. Manajemen kelas yang baik jika semua aspek ini diperhatikan secara seimbang dan serius dengan strategi yang baik pada tahapan perencanaan, pengorganisasian, implentasi atau pelaksanaan proses belajar dan tahapan evaluasi belajar.

Secara sederhana dari kaca mata evaluasi manajemen kelas aspek pembelajaran guru sangat terkait dengan tiga unsur penting yang saling terkait dan saling berpengaruh dalam proses belajar. Ketiga unsur kunci pembelajaran adalah: Pertama, tujuan dan manfaat (objectives) dari kegiatan belajar yang dilakukan, dinilai dan diukur se- cara objektif tercapai atau tidak. Kedua, pengalaman belajar siswa dan guru (learner experiences). Pada unsur pengalaman belajar dari kaca mata evaluasi akan digali secara kualitaitif melalui observasi, wawancara, dokumen portofolio siswa. Tujuan dari evaluasi kualitatif tersebut akan membantu guru untuk merangkum secara detail, teliti dan holistik pengalaman siswa secara individual atau kelompok. Ketiga, penilaian pembelajar (learner appraisal). Penialian ini bertujuan melihat dan mendapatkan hasil belajar siswa dengan instrumen alat ukur berupa tes yang disiapkan oleh guru. Proses ini dilakukan dengan lensa penilaian sederhana tetapi dengan komponen yang integral dan utuh. Hal ini tergambar dalam bagan penialan di bawah ini.

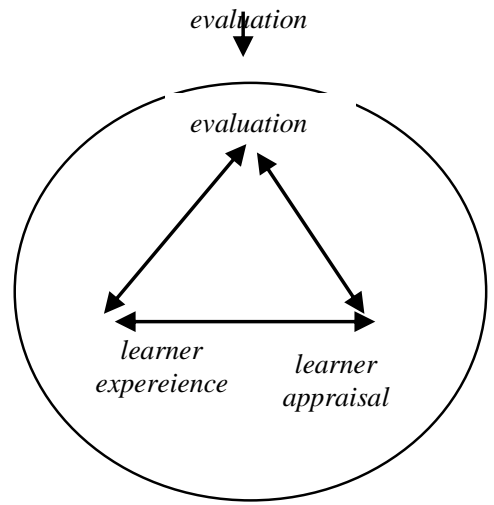

Gambar 4. Bagan Evaluasi Proses Belajar Mengajar

Dari bagan evaluasi ini terlihat bahwa evaluasi terhadap faktor pengalaman belajar menekankan pentingnya kemampuan guru melakukan refleksi dan tindakan. Tindakan guru dan siswa melahirkan pengalaman, dan refleksi guru terhadap tindakan dan pengalamannya melalui abstraksi melahirkan pengalaman baru untuk tindakan dan rencana baru. Namun perlu diingat bahwa tidak semua pengalaman menghasilkan pembelajaran sehingga penting bagi guru untuk melakukan evaluasi diri dan evaluasi proses pengajaran dengan model yang beragam tidak terbatas pada pola-pola konvensional saja. Guru harus bergerak dengan mencari dan menerapkan model evaluasi belajar berbasis pengalaman terhadap proses belajar-mengajar yang ia lakukan. Sejalan dengan upaya membuat dan 
menciptakan kelas sebagai episentrum belajar maka model evaluasi berbasis refleksi dan aksi partisipatif antara guru dan siswa untuk mengembangkan keahlian personal guru. Evaluasi partisipatif yang dikembangkan ini dapat digunakan guru untuk memperkaya strategi dan model evaluasi sekaligus memperluas dan meningkatkan skil personal guru dalam merancang dan mengembangkan evaluasi pembelajaran yang partisipatif dan produktif.

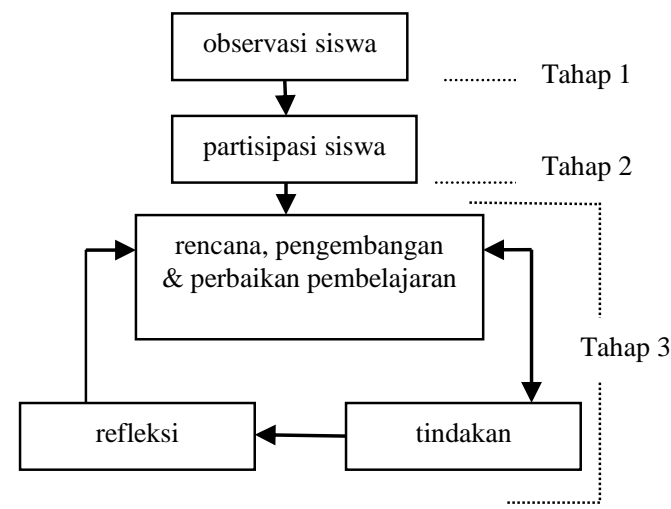

Gambar 5. Bagan Evaluasi Pembelajaran Partisipatif untuk

Pengembangan Personal Guru dalam Pembelajaran (Girvan, Conneely, \& Tangney, 2016, p. 132).

Aspek penting lain bahwa kualitas proses belajar dan bias perilaku siswa dalam kelas juga turut ditentukan oleh model autoritas atau sikap guru dan siswa di kelas. Ada beberapa autoritas yang guru miliki dan bisa diterapkan guru sesuai kondisi kelas dan karakteristik siswa. Bila guru semakin mengenal dan memahami karakter siswa dan memahami makna dan orientasi kelas sebagai episentrum belajar maka semakin mempermudah dia melaksanakan manajemen erilaku kelas yang sukses. Ia bisa menerapkan model otoritas yang bersifat attractive/referent authority, expert authority, reward authority, coercive and position/legitimate authority. Otoritas guru dapat memberikan keuntungan tetapi juga menjadi penghambat dalam proses belajar tergantung bagaimana guru sendiri menggunakan otoritasnya (Shindler, 2018, pp. 1-2). Manajemen otoritas guru sangat menentukan pola-pola pembelajaran, suasana dan iklim belajar serta perilaku yang ditimbulkan dari otoritas yang dimiliki oleh guru sendiri. Otoritas guru adalah cerminan kekuatan, kekuasaan (power) guru untuk mempengaruhi, memotivasi minat, kreativitas dan daya inquiri siswa dalam belajar. Hasil penelitian dari Hendrickx dan kawan-kawan menjelaskan bahwa pentingnya guru melakukan manajemen perilaku siswa dalam pembelajaran untuk memelihara ekologi teman sebaya dalam menjaga interaksi yang sehat diantara siswa dan menghindari konflik dan tindak agresi siswa (Hendrickx et al., 2016,p. 32).

\section{Simpulan}

Berdasarkan hasil penelitian dan pembahasan dapat disampaikan simpulan sebagai berikut. Kelas sebagai pusat gravitasi pembelajaran memprasyaratkan beberapa hal yaitu sebagai berikut.

Pertama, enam aspek kunci dalam hexagonal manajemen kelas adalah unsur penting yang harus dilibatkan dalam proses pendidikan dan pembelajaran di sekolah dasar. Sikap guru, karakteristik siswa, infrastruktur kelas, infrastruktur teknologi, daya dukung sekolah dan lembaga atau pemerintah menjadi syarat mutlak bagi kunci belajar sukses. Kedua, Pentingnya guru memiliki pemahaman yang luas terhadap teori dan paksis manajemen dengan segala element penting dalam proses belajar di kelas karena pada dasarnya mengajar adalah sebuah proses mutu. Karena itu guru harus mencoba beberbagai model evaluasi untuk meningkatkkan dan mengembangkan profesionalitasnya.

Ketiga, Pentingnya kekuatan daya dukung support system baik mutu sistem, mutu layanan, infrastruktur kelas dan infrastruktur teknologi, dukungan sekolah, lembaga dan pemerintah sebagai elemen penting dalam manajemen kelas untuk mewujudkan belajar sukses bagi setiap siswa. Keempat, Ruang kelas harus menjadi pusat kekuatan informasi pengetahuan, nilai-nilai, yang membangun kepribadian dan keterampilan sosial siswa. Dalam setiap pergerakan aktivitas belajar infrastuktur kelas 
dan infrastuktur teknologi harus memadai untuk mendukung proses belajar di dalam kelas maupun di luar ruang kelas sehingga daya kritis sukses belajar siswa dapat diciptakan dalam manajemen kelas guru.

Berdasarkan simpulan tersebut, dapat disampaikan saran sebagai berikut. Dalam upaya mewujudkan manajemen elas yang sukses maka perlu disarankan beberapa hal berikut. Pertama, untuk mewujudkan manajemen kelas yang baik dalam pembelajaran di kelas penting sekali bagi sekolah untuk mencoba menerapkan hexagonal manajemen mutu karena konsep ini sangat relevan dengan tuntuan perkembangan pendidikan saat ini di era revolusi industri 4.0. Inovasi, kolaborasi, net working, kemampuan literasi teknologi adalah kata kunci keberhasilan dalam menciptakan pembelajaran atau menyiapkan kelas yang baik untuk belajar yang sukses. Kedua, lingkungan dan sumber daya kelas maupun sekolah perlu dimanfaatkan guru karena lingkungan fisik memberi dan mengundang berbagai jenis pembelajaran, dan berkontribusi dalam membangun sikap yang berbeda terhadap pembelajaran siswa oleh guru.

Ketiga, setiap sekolah perlu membudayakan budaya mutu artinya harus sering dibiasakan untuk berpkir, merasa dan bertindak dengan visi manajemen mutu baik pada aspek layanan belajar yang berkualitas, kesiapan dan ketersediaan infrastruktur kelas dan teknologi yang memadai. Artinya disetiap ruang kelas selalu tersedia cukup lengkap dan berkualitas buku-buku bacaan siswa, media belajar, alat peraga, akses internet yang memadai untuk siswa. Karena itu guru dan siswa harus melek teknologi. Keempat, pembelajar sukses adalah sekaligus user dan learner. Karena itu assesment rutin perlu dilakukan guru sendiri di kelasnya masing-masing, baik untuk dirinya sendiri maupun terhadap siswa sebagai bentuk sikap kritis guru dalam mencapai manajemen sukses untuk guru sukses.

\section{Daftar Pustaka}

Ary, D., Jacobs, L. C., Sorensen, C., \& Razavieh, A. (2006). Introduction to research in education (eight). Belmont: wadsworth Cengage Learning.

Baxter, P., \& Jack, S. (2008). Qualitative case study methodology: Study design and implementation for novice researchers. The Qualitative Report, 13(4), 544-559.

https:// doi.org/citeulike-articleid:6670384

Bronfenbrenner, U., \& Morris, P. A. (2006). The bioecological model of human development. In \& W. D. (Eds. In R. M. Lerner (Ed.), Theoretical models of human development: vol. 1. Handbook of child psychology (six, pp. 793-828). Hoboken, NJ:JohnWiley \&Sons.

Claxton, G. (2014). School as an epistemic apprenticeship: the case of building learning power. The british Psychology Society (Vol. 37). Mylton Keynes: British Psychological Society. https:/ / doi.org/10.1080/02103702.201 4.929863

Dewey, J. (1900). The school and society. New York: The University Of Chicago Press: Mc Clure, Philip and company. Retrieved from https://archive.org/details/schoolsoc iety00deweiala

Doyle, W. (1986). Clasroom management techniques and student discipline. Arizona: University of Arizona.

Girvan, C., Conneely, C., \& Tangney, B. (2016). Extending experiential learning in teacher professional development. Teaching and Teacher Education, 58, 129-139. https:// doi.org/10.1016/j.tate.2016.04 .009

Glassman. (2002). A response to "dewey and vygotsky: Society, experience, and inquiry in educational practice." Educational Researcher, 31(5), 21-23. https:// doi.org/10.3102/0013189X031 005021

Hastings, S. (2006). Issues and solutions for teacher. London and New York: 
Routledge Taylor \& Francis Group.

Hendrickx, M. M. H. G., Mainhard, M. T., Boor-klip, H. J., Cillessen, A. H. M., \& Brekelmans, M. (2016). Social dynamics in the classroom: Teacher support and conflict and the peer ecology. Teaching and Teacher Education, 53, 30-40. https:// doi.org/10.1016/j.tate.2015.10 .004

Lee-post, A. (2009). E-learning success model : an information systems perspective. Electronic Journal of ELearning, 7(1), 61-70.

Lee, J. (2008). Multicultural Education in South Korean Public Elementary Schools: An Analysis of Teachers' Experiences and Perspectives and School Curriculum, 9.

Ozkan, S. (2015). Evaluating learning management systems : Hexagonal elearning assessment (HELAM).
European and Mediterranean Conference on Information Systems, European $a($ January 2008), 1-17.

Selim, H. M. (2007). Critical success factors for e-learning acceptance: Confirmatory factor models. Computers $\mathcal{E}$ Education, 49, 396-413. https:// doi.org/10.1016/j.compedu.2 005.09.004

Shindler. (2018). Teacher authority as power. Cllasroom Management Resource Page of California State University, 1-2.

Stake, R. E. (2005). Qualitative case studies. In N. K. Denzin \& Y. . Lincoln (Eds.), The Sage Handbook of Qualitative Research (pp. 443-466). Thousand Oaks, CA.: Sage Publications Ltd.

Stronge, J.H., Tucker, P.D., \& Pamela D., \& Hindman, L. (2019). Handbook for qualities of effective teachers. $A S C D$, 1-5. 